\title{
Pengembangan E-Modul IPA Berbasis Adobe Flash Pada Tema Makananku Kesehatanku Untuk Kelas VIII SMP
}

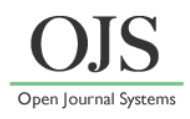

\author{
Ayunda Putri*, Sjaifuddin, Liska Berlian \\ Program Studi Pendidikan IPA, FKIP, Universitas Sultan Ageng Tirtayasa \\ *Email: ayundaputri1998@gmail.com
}

DOI: https://doi.org/10.33369/pendipa.6.1.143-150

\begin{abstract}
The development of Adobe Flash-based science e-modules on the theme of my health, my food for class VIII of junior high school is aimed at developing and knowing the level of validity of the Adobe Flashbased science e-modules that have been made. The research method used is research and development (Research \& Development). The research and development model used is a modified 4D model from Triyanto (2012) which is limited to three stages. The stages are, the definition stage (Define), the design stage (Design), and the development stage (Develop). The results showed that the level of validity of the Adobe Flash-based science e-module, my food, my health, for class VIII junior high school obtained an overall average score of $95.4 \%$ with a very valid category.
\end{abstract}

Keywords: Science E-Module Development, Adobe Flash, My Food My Health.

\begin{abstract}
ABSTRAK
Pengembangan e-modul IPA berbasis Adobe Flash pada tema makananku kesehatanku untuk kelas VIII SMP ini bertujuan untuk mengembangkan dan mengetahui tingkat kevalidan e-modul IPA berbasis Adobe Flash yang telah dibuat. Metode penelitian yang digunakan adalah penelitian dan pengembangan (Research \& Development). Dengan model penelitian dan pengembangan yang digunakan yaitu model 4D modifikasi dari Triyanto (2012) dengan dibatasi menjadi tiga tahapan. Adapun tahapan nya yaitu, tahap pendefinisian (Define), tahap perancangan (Design), dan tahap pengembangan (Develop). Hasil penelitian menunjukkan bahwa tingkat kevalidan pada e-modul IPA berbasis Adobe Flash tema makananku kesehatanku untuk kelas VIII SMP memperoleh nilai rata-rata keseluruhan sebesar 95,4\% dengan kategori sangat valid.
\end{abstract}

Kata kunci: Pengembangan E-modul IPA; Adobe Flash; Makananku Kesehatanku.

\section{PENDAHULUAN}

Pembelajaran IPA mempunyai kedudukan sangat penting bagi kehidupan manusia dan memiliki kaitan yang luas, dikarenakan IPA ialah mata pelajaran yang dapat meningkatkan rasa ingin tahu manusia terhadap perkembangan teknologi. Saat ini pembelajaran IPA pada jenjang SMP dikembangkan menjadi mata pelajaran IPA terpadu, dengan memadukan beberapa teori dari ranah ilmu Fisika, Biologi, Kimia serta Ilmu Pengetahuan Bumi dan Antariksa atau disebut dengan IPBA. Penelitian ini menggunakan model keterpaduan yaitu model keterpaduan Connected, model keterpaduan Connected adalah model keterpaduan yang membelajarkan sejumlah KD yang terdiri dari KD utama dan KD pendukung (Nugraheni, dkk., 2015). Pembelajaran keterpaduan dilakukan dengan mengangkat tema makananku kesehatanku. Tema ini memadukan konsep dari bidang Biologi dan Kimia. KD yang dipadukan pada tema makananku kesehatanku diantaranya KD 3.5 mengenai sistem pencernaan pada manusia, KD 3.6. mengenai zat aditif serta KD 3.3 mengenai unsur dan senyawa. Pemilihan tema makananku kesehatanku ini karena tidak terpisahkan pada kehidupan, ketika makanan yang dikonsumsi tidak sehat, mengandung zat 
aditif maka akan menimbulkan berbagai jenis gangguan pada sistem pencernaan manusia.

Mata pelajaran IPA terpadu memiliki beberapa konsep sehingga dapat membuat satu tema namun di dalam kajian bidang yang berbeda. Oleh karena itu waktu yang dapat digunakan lebih efektif serta efisien dalam pencapai tujuan pembelajaran. Adapun agar dapat mencapai tujuan pembelajaran yang efisien serta efektif perlu menggunakan media pembelajaran (Setyowati, 2013).

Media secara sederhana merupakan semua alat yang penggunaanya untuk memaparkan isi materi pembelajaran yang akan membuat siswa mudah dalam mendapatkan pengetahuan, informasi, pengalaman serta keterampilan dalam proses belajar (Taufiq \& Widiyatmoko, 2014). Siswa akan dengan mudah dapat mengerti dan memehami materi pembelajaran apabila menggunakan media pembelajaran, tujuan pembelajaran akan tercapai tergantung pada media yang digunakan serta penyampaian strategi pembelajaran.

Dilihat dari keadaan saat ini Covid-19 yaitu virus corona sedang menyerang dunia. Virus corona adalah virus yang menimbulkan penyakit pada manusia. Karena pandemi ini semua negara harus mengantisipasi dan memberikan respon dan juga harus waspada. Selain itu dampak dari pandemi ini ialah terhadap pendidikan, yang mengarah kepada penutupan luas sekolah dan memungkinkan belajar di rumah. Hal ini dilakukan tindak lanjut oleh menteri pendidikan dan kebudayan (kemendikbud) yang mengkoordinasikan pembelajaran melalui sistem daring (online) atau pembelajaran jarak jauh (Setiawan, 2020).

Pembelajaran daring (online) digunakan agar dapat mencapai standar pendidikan dan teknologi informasi, penggunaan komputer dan smartphone akan memudahkan pembelajaran karena siswa dan guru saling terhubung. Sehingga dengan pemanfaatan teknologi tadi pembelajaran akan tetap berjalan walaupun sedang dalam masa pandemi virus corona (Pakpahan dan Fitriani, 2020).

Seiring berkembangnya teknologi yang pesat memungkinkan peranan teknologi informasi dan komunikasi dalam pembelajaran sehingga tercapainya pembelajaran dengan baik. Hasil dari perkembangan teknologi saat ini dibidang pendidikan salah satunya adalah modul cetak yang dimodifikasi menjadi modul elektronik atau yang disebut $e$-modul (Setiadi \& Zainul, 2019).

Modul elektronik (e-modul) adalah media yang di dalamnya terdapat batasan-batasan dan metode serta terdapat alat untuk mengevaluasi yang dibuat dengan sistematis serta menarik sesuai dengan tingkat kompleksitasnya secara elektronik untuk mencapai kompetensi yang diinginkan. Melalui $e$-modul siswa tertarik dan termotivasi untuk mengikuti kegiatan pembelajaran, dikarenakan $e$-modul memiliki kelebihan yang tidak dimiliki oleh modul cetak yaitu, e-modul ini lebih interaktif karena dapat menampilan gambar, animasi, video, audio, untuk mencapai tujuan pembelajaran. E-modul juga dapat menjadi solusi karena keterbatasan waktu dan siswa bisa belajar mandiri terutama dalam kondisi pandemi virus corona (Hasanah \& Dewi, 2012).

Berdasarkan analisis kebutuhan untuk mendapatkan fakta yaitu potensi dan masalah yang terjadi dilapangan maka dilakukan wawancara guru IPA SMPN 17 Kota Serang, didapatkan bahwa bahan ajar yang digunakan masih modul cetak serta media pembelajaran yang digunakan yaitu power pint atau media konvensional. Sehingga pada proses pembelajaran terasa monoton dan bosan karena pembelajaran tidak menarik serta membuat siswa kesulitan dalam memahami materi. Adapun kendala lain yang dihadapi pada masa pandemi saat ini siswa kesulitan dalam proses pembelajaran karena pembelajaran yang dilaksanakan dengan daring (online) tidak semua siswa mengikuti pembelajaran dengan baik dan efektif.

Dilihat dari potensi masalah yang telah diketahui melalui wawancara maka perlu dilakukan pengembangan modul pembelajaran berupa modul interaktif atau yang disebut $e$ modul. Menurut Darmawan (2012) menyatakan bahwa software yang dapat digunakan untuk pembelajaran yaitu software Adobe Flash. software ini dilengkapi dengan gambar, dan gambar, animasi, audio, video bahkan film untuk menjelaskan materi sehingga pembelajaran lebih menarik. Selain itu, Adobe Flash adalah sebuah software yang memiliki kegunaan untuk pembuatan $e$-modul yang bersifat interaktif. 
Maka dari itu, dikembangkanlah e-modul IPA berbasis Adobe Flash. Dengan dikembangkannya e-modul ini media pembelajaran akan berjalan secara efektif karena proses pembelajaran akan menarik serta tidak membosankan. Pembelajaran akan berlangsung dengan efisien karena tidak hanya dapat dilakukan dikelas, melainkan dapat diakses melalui komputer dan smartphone serta dilengkapi dengan teks, gambar, video, animasi, dan audio dengan ini siswa dapat memahami materi dengan mudah karena $e$-modul ini mudah di jalankan dan tidak kenal jarak dan waktu.

Berdasarkan penelitian dan pengembangan maka permasalahan yang dapat diuraikan yaitu, (1) Bagaimana mengembangkan e-modul IPA berbasis Adobe Flash pada tema makananku kesehatanku untuk kelas VIII SMP?, dan (2) tingkat kevalidan e-modul IPA berbasis Adobe Flash pada tema makananku kesehatanku untuk kelas VIII SMP.

\section{METODE PENELITIAN}

Metode yang digunakan yaitu metode penelitian serta pengembangam Research \& Development (R\&D). Metode ini bertujuan agar dapat menguji kevalidan serta menghasilkan produk (Sugiyona, 2015). Model penelitian yang dipakai ialah model four-D (4-D) modified dari Triyanto (2012). Dengan dibatasi beberapa tahap yaitu, tahap pendefinisian (Define), tahap perancangan (Design), dan tahap pengembangan (Develop). yaitu sampai validasi ahli dan perbaikan produk dikarenakan kondisi yang tidak memungkinkan serta keterbatasan waktu. Berikut ini merupakan tahapan Four-D.

\section{Tahap Pendefinisian (Define)}

Tahap ini bertujuan memperoleh berbagai data yang berkaitan pada $e$-modul IPA yang akan dikembangkan. Tahap pendefinisian memiliki langkah-langkah yaitu:

a. Analisis Kebutuhan

Analisis ini bertjuan untuk memeproleh kebutuhan serta ketersediaan e-modul IPA berbasis Adobe Flash pada tema makananku kesehatanku di SMPN 17 Kota Serang. Berdasarkan hasil analisis kebutuhan media pembelajaran melalui wawancara guru IPA. Peneliti memperoleh beberapa informasi yaitu, guru masih menggunakan media yaitu power point. Minimnya penggunaan media pembelajaran menyebabkan siswa jenuh dan bosan, kurang adanya inovasi pada tampilan dan penggunaan gambar serta membuat siswa kesulitan dalam memahami materi, terutama pada saat pandemi sekarang ini pembelajaran dilakukan daring (online) tidak semua siswa mengikuti pembelajaran dengan baik dan efektif.

b. Analisis Kurikulum

Tahap ini bertujuan untuk mengetahui kurikulum yang dipakai oleh SMPN 17 kota serang, kurikulum yang digunakan disekolah tersebut adalah kurikulum 2013. Peneliti menganalisis kompetensi dasar serta kompetensi inti yang ingin dikuasai oleh siswa. Menganalisis indikator ketercapaian dan menganalisis materi pokok. Kompetensi inti yang diapkai yaitu, kompetensi 1 sampai 5, kemudian kompetensi dasar yang dipakai yaitu, KD 3.5 yang menjelaskan sistem pencernaan pada manusia, KD 3.6 zat aditif serta KD 3.3 zat dan karakteristiknya bagian unsur senyawa.

c. Analisis Konsep

Tahap analisis bertujuan untuk menganalisis konsep pembelajaran. Penelitian ini menggunakan materi tema makananku kesehatanku. Model keterpaduan Connected yaitu model keterpaduan yang membelajarkan beberapa KD yang konsep-konsepnya saling berhubungan/berkaitan yang terdiri dari KD utama dan KD pendukung (Fogarty, 1991) konsep yang saling berhubungan pada e-modul yaitu sistem pencernaan pada manusia, dan zat aditif serta unsur senyawa, KD utama yang diambil yaitu materi sistem pencernaan pada manusia yang berhubungan dengan KD pendukung yaitu zat aditif yang terdapat ada di dalam makanan serta minuman sehingga berkaitan dengan unsur senyawa yang juga sebagai KD pendukung.

d. Analisis Perumusan Tujuan Pembelajaran

Perumusan ini digunakan agar mencapai tujuan pembelajaran yang dirumuskan sejalan dengan KI \& KD yang digunakan pada materi pembelajaran dengan tema makananku kesehatanku.

\section{Tahap Perancangan (Design)}

Tahap ini digunakan untuk mempersiapkan segala kebutuhan yang akan dipergunakan untuk merancang e-modul. Proses perancangan yang 
dilakukan terdiri dari beberapa tahap, yaitu membuat bagian alur (flowchart), pembuatan storyboard, pengumpulan referensi, desain produk, dan penyusunan instrumen penilaian, sebagai beriku :

a. Pembuatan Flowchart

Flowchart yang dimaksud adalah suatu alur pada e-modul IPA berbasis Adobe Flash, flowchat digambarkan dalam bentuk simbolsimbol yang digunakan untuk menggambarkan alur dari suatu program, misalnya setelah halaman intro akan menuju halam utama.

b. Pembuatan Storyboard

Storyboard ini akan menunjukan aktivitasaktivitas yang akan dilakukan oleh siswa. storyboard disajikan dalam bentuk tabel dengan beberapa komponen yaitu: nomor, nama menu, deskripsi singkat yang menjelaskan tentang menu tersebut, tombol yang tersedia tampilan visual dari menu tersebut.

c. Pengumpulan Referensi

Pengumpulan referensi ialah pengumpulan bahan yang diperlukan e-modul berbasis Adobe Flash yaitu, gambar, animasi, video, dan materi terkait sistem pencernaan pada manusia (tema makananku kesehatanku) serta mempersiapkan software Adobe Flash Professional CS6 untuk merancang $e$-modul.

d. Pembuatan Desain Produk

pembuatan desain produk merupakan tahap merancang e-modul IPA yang akan dikembangkan. E-modul yang dirancang terdiri dari beberapa menu yaitu halaman utama dan halaman menu. Halaman utama terdiri dari beberapa komponen yaitu, tentang e-modul, profil pengembang dan bantuan. Sedangkan pada halaman menu terdiri dari petunjuk, kompetensi, peta konsep, materi dan evaluasi. Berikut ini merupakan desain awal produk e-modul IPA berbasis Adobe Flash.

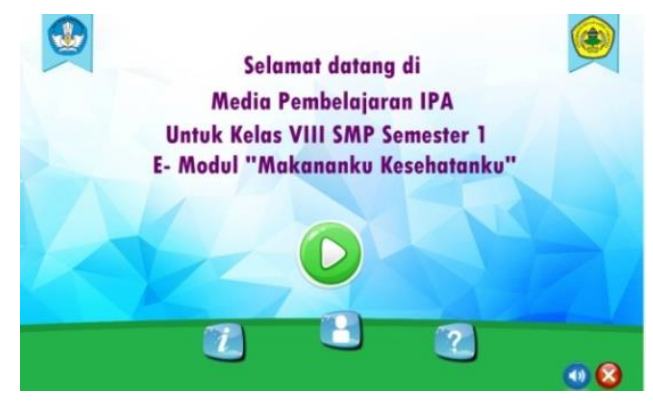

Gambar 1. Desain Awal Produk e. Menyiapkan Instrumen Validasi

Tahap yang dilakukan sebelum validasi ahli adalah dibuatnya instrumen yang akan digunakan oleh tim ahli. Validasi ini digunakan agar memperoleh kevalidan e-modul IPA berbasis Adobe Flash. Pada aspek isi, bahasa, penyajian, proses pembelajaran, tampilan media dan manfaat media.

\section{Tahap Pengembangan (develop)}

Tahap ini ialah tahapan validasi e-modul yang dihasilkan untuk memperoleh penilaian dari segi aspek materi dan media. Langkah-langkah tahap develop yaitu e-modul awal yang sudah dihasilkan selanjutnya dilakukan validasi $e$ modul. Proses validasi $e$-modul dinilai oleh tim ahli agar dapat memperoleh penilaian kevalidan produk. Teknik analisis deskriptif kuantitatif serta deskriptif kualitatif untuk menganalisis hasil validasi ahli. Kuantitatif ialah data yang didapatkan berbentuk saran dari tim ahli dalam bentuk angket ahli materi, ahli media, dan penilaian guru. Penelitia ini memakai penskoran skala likert 1 sampai 5. Berikut ini merupakan penskoran untuk kevalidan $e$-modul IPA berbasis Adobe Flash pada tabel 1.

Tabel 1. Skor Penilaian Skala Likert

\begin{tabular}{cc}
\hline Pertanyaan & Skor \\
\hline SB (Sangat Baik) & 5 \\
\hline B (Baik) & 4 \\
\hline C (Cukup)) & 3 \\
\hline D (Kurang) & 2 \\
\hline SK (Sangat Kurang) & 1 \\
\hline
\end{tabular}

Penilaian tim ahli, kemudian akan dihitung skor rata-ratanya dari setiap aspek untuk menentukan kevalidan e-modul IPA berbasis Adobe Flash yang dikembangkan. Berikut ini merupakan rumus perhitungan kevalidan yaitu:

$$
P=\frac{n}{N} \times 100 \%
$$

Keterangan:

$\mathrm{P}=$ Persentase respon

$\mathrm{n}=$ Jumlah skor yang diperoleh

$\mathrm{N}=$ Jumlah skor kriteria

$100 \%=$ Bilangan tetap 
Deskriptif kualitatif merupakan data yang menyajikan penilaian tim ahli terkait kevalidan e-modul yaitu e-modul berbasis Adobe Flash pada tema makananku kesehatanku. Persentase hasil validasi disesuaikan dengan kategori sebagai berikut:

Tabel 2. Kategori Uji Kevalidan

\begin{tabular}{cc}
\hline Koefisien Korelasi & Kategori \\
\hline $81-100 \%$ & Sangat Valid \\
\hline $61-80 \%$ & Valid \\
\hline $41-60 \%$ & Cukup Valid \\
\hline $21-40 \%$ & Kurang Valid \\
\hline $0-20 \%$ & Tidak Valid \\
\hline & (modifikasi Riduwan, 2012)
\end{tabular}

\section{HASIL DAN PEMBAHASAN}

Penelitian ini memiliki tujuan yaitu mengembangkan e-modul IPA berbasis Adobe Flash pada tema makananku kesehatanku untuk kelas VIII SMP. Penelitian dilakukan berdasarkan model Four-D (4-D) dibatasi menjadi tahap pendefinisian (Define), tahap perancangan (Design), tahap pengembangan (Develop). Tahap pendefinisian (Define), terdiri dari tahap analisis kebutuhan, tahap analisis kurikulum, tahap analisis konsep, serta tahap analisis tujuan pembelajaran.

Tahap Perancangan (design) e-modul dilakukan dengan beberapa tahap yaitu membuat bagian alur flowchart, pembuatan storyboard, pengumpulan referensi, pembuatan desain produk, dan Penyusunan instrument penilaian.

Tahap Pengembangan (develop) merupakan tahap validasi e-modul yang dihasilkan untuk memperoleh penilaian dari segi aspek materi dan media, yang selanjutnya akan digunakan sebagai perbaikan e-modul atau yang disebut dengan tahap revisi. Penialaian dilakukan oleh tim ahli yaitu dosen pendidikan IPA UNTIRTA serta guru IPA SMPN 17 Kota Serang dengan mengisi lembar angket instrumen validasi ahli materi, media dan penilaian guru. Produk dikatakan valid apabila kriteria penilaian minimal berada pada kriteria valid (Santi \& Rusgianto, 2016). Hasil dari seluruh penilaian validator adalah sebagai berikut:

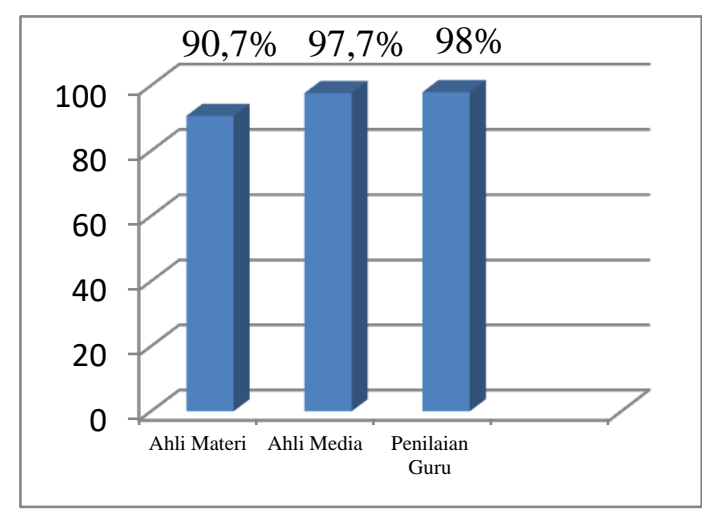

Gambar 2. Hasil Validasi Produk

Pada gambar diatas dapat diketahui bahwa hasil validasi materi mendapatkan nilai $90,7 \%$ dengan kategori sangat valid. Validasi ini didasarkan pada aspek isi, aspek bahasa serta aspek penyajian. Sedangkan hasil validasi ahli media mendapatkan nilai $97,7 \%$ dengan kategori sangat valid. Validasi ini didasarkan pada aspek tampilan media serta manfaat media. Selanjutnya penilaian guru mendapatkan nilai $98 \%$ mendapatkan kategori sangat valid. Penilaian guru pada aspek proses pembelajaran, tampilan media serta manfaat media.

\section{Validasi Ahli Materi}

Validasi materi merupakan tahapan dimana para ahli menilai materi yang terdapat pada $e$-modul IPA berbasis Adobe Flash pada tema makananku kesehatanku. Validasi materi ini didasarkan pada aspek isi, aspek bahasa, serta aspek penyajian. Hasil validasi ahli materi mendapatkan nilai sebesar $90,7 \%$ adapun penilaian beberapa aspek pada gambar berikut:

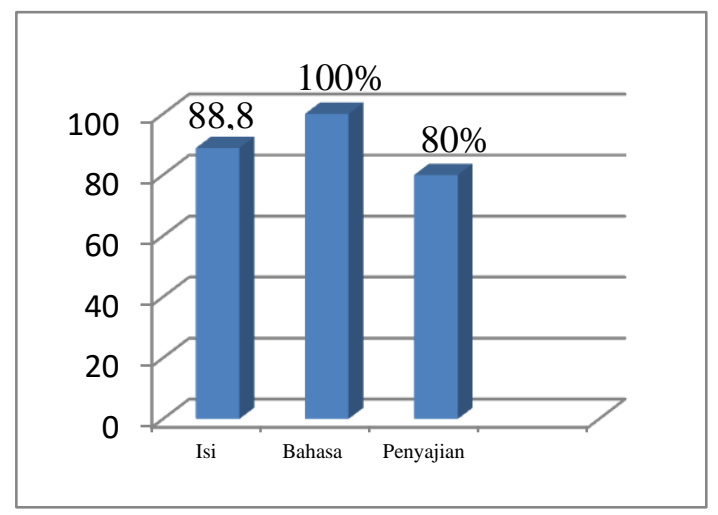

Gambar 3. Hasil Validasi Ahli Materi 
Pada gambar diatas aspek isi mendapatkan nilai $88,8 \%$ sehingga memperoleh kategori sangat valid, ini dikarenakan menurut ahli $e$ modul IPA pada aspek isi yaitu kompetensi dasar, dan kompetensi inti, serta indikator pembelajaran sudah sesuai dengan tingkat berpikir kognitif siswa. Hasil penilaian ini selaras dengan pendapat wulandari dan Purwanto (2017), yaitu, kesesuaian pada aspek isi adalah sesuainya kompetensi dasar, kompetensi inti, serta tujuan dalam pembelajaran, serta materi sesuai kognitif siswa. Selain itu, kesesuaian pada kedalaman dan keakuratan materi serta kemudahan memahami materi, keakuratan gambar dengan video dalam materi serta kesesuaian latihan soal. Menurut ahli materi bahwa pada e-modul perlu ditambahkan menu halaman untuk tujuan pembelajaran dan model keterpaduan.

Aspek bahasa mendapatkan nilai sebesar $100 \%$ sehingga termasuk ke dalam kategori sangat valid. Aspek bahasa merupakan aspek dengan nilai persentase tertinggi karena penggunaan bahasa pada e-modul mudah dipahami dengan kalimat yang sederhana serta penulisan yang sesuai dengan EYD dan KBBI. Penilaian ini didukung oleh pernyataan Depdiknas (2017), yaitu kalimat yang sederhana dan dapat menyampaikan materi dengan jelas adalah $e$-modul yang baik.

Aspek penyajian mendapatkan nilai sebesar $80 \%$ sehingga termasuk ke dalam kategori sangat valid. Penilaian ini menunjukan bahwa sistematika penyajian materi sudah konsisten.

\section{Validasi Ahli Media}

Validasi ahli media merupakan tahapan dimana para ahli menilai produk e-modul IPA berbasis Adobe Flash pada tema makananku kesehatanku. Validasi media ini didasarkan pada aspek tampilan media dan manfaat media dengan mendapatkan nilai sebesar $97,7 \%$ dan termasuk mendapatkan kategori sangat valid. Dapat dilihat hasil validasi media medapatkan nilai kevalidan yang berbeda dari masing-masing aspek sebagai berikut :

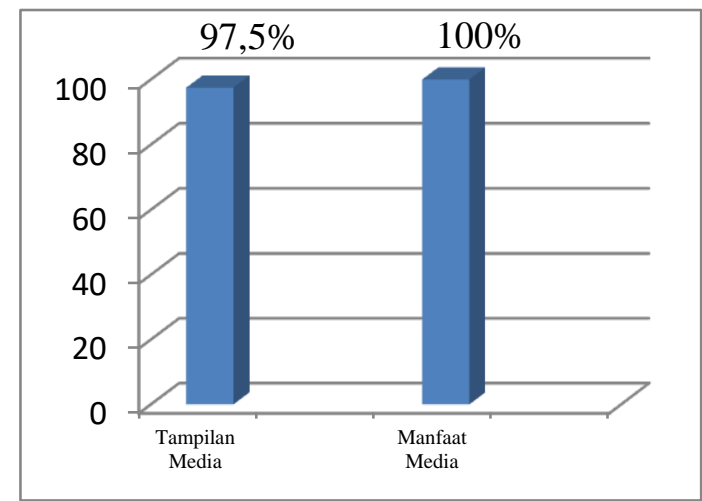

Gmbar 4. Hasil Vlidasi Ahli Media

Pada gambar 4 menunjukkan penilaian ahli media terhadap tampilan media mendapatkan nilai $97,5 \%$ dengan kategori sangat valid, hasil penilaian ini dikarenakan bahwa tampilan pada e-modul menarik, penggunaan jenis huruf serta ukuran huruf pada $e$-modul sudah sesuai dan mudah untuk dibaca, serta ketepatan penggunaan warna pada $e$-modul dan keseimbangan warna pada teks, gambar dan background dapat membuat $e$-modul ini lebih jelas. Hasil penilaian ini sesuai dengan pernyataan Sanjaya (2011), yang mengatakan dalam penggunaan tulisan perlu memperhatikan warna dasar dengan warna teks yang digunakan sehingga tulisan tidak membosankan dan menjadi jelas. Namun terdapat saran dari ahli bahwa menu materi belum berikan keterangan bahwa tiap sub tema materi dapat diklik.

Keseimbangan komposisi gambar dan video pada $e$-modul serta kejelasan gambar dan video yang dapat diputar mampu menjelaskan materi tema makanaku kesehatanku. Hal ini didukung oleh pernyataan Hasanah dan Nulhakim (2015), bahwa gambar dan video pembelajaran seharusnya dapat memperjelas konsep materi yang disampaikan, mampu meningkatkan motivasi belajar siswa serta memiliki peran komunikatif dalam tampilannya. Tombol-tombol navigasi yang digunakan pada $e$-modul dari tata letak, bentuk, dan ukuran sudah konsisten diseluruh program serta alur pengoperasian program sederhana dan pengelolaan navigasi yang mudah sehingga memudahkan siswa pada penggunaan e-modul. Penilaian ini sesuai pernyataan Sanjaya (2012), bahwa program multimedia harus disusun secara sederahana 
sehingga mudah dalam pengoperasiannya. selain itu penggunaan waktu yang tidak berlebihan dan menarik sesuai dengan perkembangan karakteristik siswa.

Aspek manfaat media mendapatkan nilai $100 \%$ dengan kategori sangat valid, dengan penilaian yang menyatakan bahwa e-modul dapat dipergunakan dengan mudah oleh siswa dengan mandiri untuk belajar. Penilaian ini selaras dengan pendapat Abi Hamid et all, (2020) salah satu kelebihan e-modul yaitu dapat digunakan berkali-kali serta lebih efisien dan fleksibel waktu karena dapat diakses kapan saja.

\section{Penilaian Guru}

Penilaian guru merupakan tahapan dimana guru menilai e-modul IPA berbasis Adobe Flash pada tema makananku kesehatanku. Validasi guru ini didasarkan pada aspek proses pembelajaran, tampilan media, dan manfaat media. Validasi guru IPA mendapatkan nilai 98\% sehingga termasuk ke dalam kategori sangat valid. Berikut merupakan penilaian pada setiap aspek.

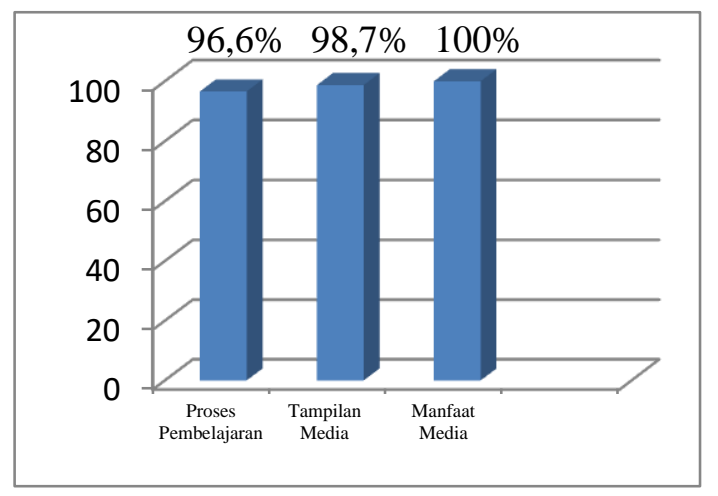

Gambar 5. Hasil Penilaian Guru

Gambar 5 menunjukkan penilaian guru IPA SMPN 17 Kota Serang. Pada aspek proses pembelajaran memperoleh nilai sebesar $96,6 \%$ sehingga mendapatkan kriteria sangat valid, dengan hasil penilaian yang menyatakan $e$-modul sudah sesuai kompetensi dasar (KD), dan kompetensi inti (KI) serta indikator pembelajaran serta tingkat berpikir kognitif siswa. Selain itu, pada e-modul ini kedalaman materi, keakuratan materi serta keakuratan gambar dengan video sudah sesuai dengan materi tema makananku kesehatanku. Sehingga membuat siswa mudah memahami materi. Kejelasan latihan soal yang disajikan dapat mengetahui perkembangan kognitif siswa. Penggunaan bahasa yang terdapat dalam $e$-modul sesuai dengan KBBI serta sesuai dengan EYD.

Aspek tampilan media memperoleh nilai sebesar 98,7\% sehingga mendapatkan kriteria sangat valid, dengan hasil penilaian yang menyatakan bahwa secara keseluruhan tampilan $e$-modul menarik, kesesuaian penggunaan jenis huruf dan ukuran huruf, ketepatan penggunaan warna pada $e$-modul dan keseimbangan warna pada teks, gambar dan background membuat siswa termotivasi untuk belajar, keseimbangan komposisi gambar dan video pada e-modul serta kejelasan gambar dan video yang dapat diputar mampu menjelaskan materi tema makanaku kesehatanku. Alur pengoperasian program sederhana dan pengelolaan navigasi yang memudahkan siswa dalam menggunakan $e$ modul pada saat proses pembelajaran.

Aspek manfaat media memperoleh nilai sebesar $100 \%$ sehingga mendapatkan kategori sangat valid, dengan hasil penilaian yang menyatakan bahwa e-modul IPA berbasis Adobe Flash ini dengan mudah pergunakan siswa dimana saja.

\section{KESIMPULAN}

Pengembangan $e$-modul IPA berbasis Adobe Flash pada tema makananku kesehatanku untuk kelas VIII SMP dikembangkan menggunakan metode Research and development. Adapun model penelitian mengadopsi model four- $D$. Modifikasi Triyanto (2012) yang terdapat 4 tahapan, tetapi penelitian ini hanya mengunakan 3 tahapan dikarenakan keterbatasan waktu dan pandemi corona. Beberapa tahap yang digunakan yaitu, tahap pendefinisian (Define), tahap perancangan (Design), dan tahap pengembangan (Develop). Tingkat kevalidan pada e-modul IPA berbasis Adobe Flash pada tema makananku kesehatanku untuk kelas VIII SMP mendapatkan nilai keseluruhan rata-rata $95,4 \%$ sehingga termasuk ke dalam kategori sangat valid.

\section{DAFTAR PUSTAKA}

Abi Hamid, M., Yuliawati, L., \& Aribowo, D. (2020). Feasibility Of Electromechanical Basic Work E-Module As A New Learning Media For Vocational Students. Journal of 
Education and Learning (EduLearn). Vol. 4, No. 2, Hal:199-211

Darmawan, D. (2012). Inovasi Pendidikan Pendekatan Praktek Teknologi Multimedia Dan Pembelajaran Online. Bandung: PT remaja rosdakarya.

Depdiknas. (2010). Pengembangan Bahan Ajar. Jakarta: Depdiknas

Fogarty, R. (1991). The Mindful School How To Integrate The Curricula. IRI.

Hasanah. N. R. dan Dewi. U. (2012). Pengembangan Media Modul Elektronik Pada Mata Pelajaran IPA Materi Pokok Kalor dan Perpindahannya di Kelas VII G SMPN 34 Surabaya. Jurnal pendidikan. Vol. 1, No. 1, Hal: 0 - 216.

Hasanah dan Nulhakim. 2015. Pengembangan Media Pembelajaran Film Animasi Sebagai Media Pembelajaran Konsep Fotosintesis. Jurnal Penelitian dan Pembelajaran IPA, Vol. 1, No. 1, Hal: 91-106

Nugraheni, N. E., Sunarno, W., \& Sarwanto, S. (2015). Pengembangan Modul IPA Terpadu Berbasis Inkuiri Terbimbing Dengan Tema Barbeque Kelas VII SMP Negeri 1 Talangmangu. Jurnal Inkuiri, Vol. 4, No. 4, Hal: 43-53

Pakpahan, R., \& Fitriyani, Y. (2020). Analisis Pemanfaatan Teknologi Informasi dalam Pembelajaran Jarak Jauh di Tengah Pandemi Virus Corona Covid-19. Journal of Information System, Applied, Management, Accounting and Research, Vol. 4, No. 2, Hal: 30-36.

Riduawan.(2012). Metode dan Teknik Menyusun Proposal Penelitian. Bandung: Alfabeta.

Sanjaya, W., (2011). Strategi Pembelajaran Berorientasi Standart Proses Pendidikan. Jakarta: Kencana.
Setiawan, A. R. (2011). Lembar Kegiatan Literasi Saintifik untuk Pembelajaran Jarak Jauh Topik Penyakit Coronavirus 2019 (COVID-19). Jurnal Edukatif. Vol. 2, No. 1, Hal: 28-37.

Setiyadi, M. W. (2017). Pengembangan Modul Pembelajaran Biologi Berbasis Pendekatan Saintifik Untuk Meningkatkan Hasil Belajar Siswa. Journal Of Educational Science And Technology (EST), Vol. 3, No. 2, Hal: 102112.

Setyowati, R., Parmin, R., \& Widiyatmoko, A. (2013). Pengembangan modul IPA berkarakter peduli lingkungan tema polusi sebagai bahan ajar siswa SMK N 11 Semarang. Unnes Science Education Journal. Vol. 2, No. 2.

Sugiyono. (2013). Metode Penelitian Pendidikan Pendekatan Kualitatif $R \& D$. Bandung: Alfabeta.

Taufiq, M., Dewi, N. R., \& Widiyatmoko, A. (2014). Pengembangan media pembelajaran ipa terpadu berkarakter peduli lingkungan tema "konservasi" berpendekatan scienceedutainment. Jurnal Pendidikan IPA Indonesia, Vol. 3, No. 2, Hal: 122-575.

Triyanto, (2012). Mendesain Model Pembelajaran Inovatif, Progresif, Konsep Landasan, Dan Implementasinya Pada Kurikulum Tingkat Satuan Pendidikan (KTSP). Jakarta: Kencana Prenada. Media Grup.

wulandari, Y., \& , Purwanto, W. E. (2017). Kelayakan aspek materi dan media dalam pengembangan buku ajar sastra lama. Jurnal Penelitian Pendidikan Bahasa dan Sastra Indonesia, Vol. 3, Hal: 162-172. 